\title{
Many-Valued Logic in the Jewish Short Stories
}

\author{
Vitaly I. Levin \\ Mathematics Department, Penza State Technological University \\ 1-a, Baidukov pr., Penza, 440039, Russia \\ e-mail:vilevin@mail.ru
}

\begin{abstract}
:
Jewish short stories (parables, tales, jokes, etc.) are explained from the viewpoint of manyvalued logic. On the basis of some examples, we show, how their contents may be logically interpreted.
\end{abstract}

Keywords: Jewish study, two-valued logic, many-valued logic.

The defect in the knowledge of mathematic evolves the hundredfold defect in the Tora's knowledge

The Gaon

\section{Introduction}

The problem of the national identification is not new. People may be considered one nation on the basis of common in behavior: common religion, common language, common traditions, connected with the same motherland. All this approaches have their own merits and demerits. For example, when we use religious identification we can call the Jews only those who follow Judaism; when we use ethnical identification - only those who speak Hebrew and knows the Jewish culture and traditions; when we use commune identification - only those who belong to the Jewish community; when we use the state identification - only those who lives in Israel and so on. We propose a new method to national self-identification of Jews: people belong to the same nation on the basis of logical ways of creating their short stories about themselves: parables, tales and so on. In particular, we consider ways of creating Jewish short stories by the implicit appealing to many-valued logic. This feature of short stories concerns intellectual activities and behaviors and can serve as one of the indices for Jewish cultural identification in the limits of the subject.

\section{Two-valued and Many-valued Logic}

Every individual uses one or another type of logic in his creative work (usually by intuition). The logic divides on two-valued and many-valued which have essential differences. These differences are as follows:

1. For two-valued logic any statement can have only two truth values: to be true or false, and the negation of one side gives another side. For many-valued logic, any statement can have some 
truth values beginning from three (true, false, indeterminate) values and the negation of given truth value can give us any other truth value in accordance with defining the negation operation.

2. For two-valued logic, it is possible to return to any statement by the way of its double negation (the law of double negation). For many valued logic, this returning is always not possible and when it is possible it is controlled by more complex laws (the law of the triple negation and so on).

3. For two-valued logic, if the given statement is true or false, the third possibility is excluded (the law of excluded middle). For many-valued logic, the choice is more complex: in one case the given statement is true, in another - its negation is true, in the third - another statement which differs from the previous is true. The concrete rule of choice depends on the negation operation definition. So, for many-valued logic the choice is more complex: in one case the given statement is true, in another its negation is true. Hence, for many-valued logic the choice of true statement from the pair (affirmation and negation) in contrast to two-valued logic is impossible.

4. For two-valued logic, the given logical statement and its negation cannot be true or false simultaneously: when one is true, another is false and vice versa. So, in two-valued logic the contradiction law holds. For many-valued logic, the simultaneous truth of two opposite statements is not eliminated. So, many-valued logic does not declare the negation of some affirmation false when the affirmation itself is true and true when it is false in contradiction to two-valued logical reasoning by this simple scheme.

5. In two-valued logic, we can transfer the negation operation over a complex statement obtained by using of the two connectives OR, AND if we change OR by AND and AND by OR (the law of de Morgan). In other words, we can replace the statement of the form NOT(A OR $B$ ) by $($ NOT $A$ ) AND (NOT $B$ ), the statement $\operatorname{NOT}(A$ AND $B$ ) by (NOT $A$ ) OR (NOT $B$ ). For manyvalued logic, such replacing is always impossible and if it is possible, it is subordinated to more complex laws, depending on the negation operation.

The difference between two-valued and many-valued logics can be represented visually by colors: the value to be true may be presented by white, the value to be false may be presented by black and other truth values by other colors. Then we can say that for two-valued logic there exists only the black-white world with simple transition from one color to another with by using the negation operation (not-white is black, not-black is white). For many-valued logic, the world is many-colored, the transition from one color to another with the help of logic can fail and if it is possible, it needs more complex operations.

\section{The Basic Hypothesis}

The Jewish short stories have logical forms described by many-valued logic. It does not mean that all the Jews are many-valued thinkers and all Gentiles are two-valued: both have thinkers of different ways. However, any interaction of individuals in telling short stories about self-identities with a similar way of thinking causes differences in the group behavior. It allows us to identify the Jews with their characteristic tradition of creating short stories about themselves. The essence of the problem of multi-cultural communications is that for two-valued thinking many-valued thinking is not so understandable, because it contents unusual ideas such as a lack of two truth values (true or false) or two evaluations of acts (good and evil) as well as an impossibility of simple transitions from one value or evaluation to another by the rules of such type: not-true is false, not-good is evil and so on.

\section{Some Typical Examples}

Some examples given below illustrate the proposed hypothesis and demonstrate how many-valued logic is used in the Jewish short stories. These examples were collected by me among short stories which are popular among the Jews in Russia. 
1. Two Jews asked their Rabbi. One of them said: "He borrowed money from me and he did not return his debt. Let him return his debt". And the Rabbi answered: "You are right". Another Jew said: "I promised to return my debt when I'll earn money, but I have no work and have no money yet". The Rabbi said: "You are right, too". But the Rabbi's wife asked: "How both of them can be right? One required to return his money and another refused to do it". "You are right, too", said the Rabbi.

2. The patriot says: "I cannot live a day out of my motherland. I understand Pushkin well. Do you remember, he calls the wish of changing the residence place the evil voice?" "Have a pity!" the Jew objects. "Why do you sit in your town if even it is very good? There are so many wonderful cities and every one of them will help me to get to know the wide world, myself and what is good in my town. So the wish for travelling is not the evil voice, but it is a real God's gift".

3. To make money or to build a just society? The merchant says: "I choose the first. I am interested in money, not in justice". The socialist says: "I choose the second, because only in the just society one can earn money honestly". "My choice is such", says the Jew-billionaire, "To make much money and endow part of it for building the just society. I consider that one does not contradict to another: making money helps me to establish the justice and the just society helps me to make money honestly".

4. To love myself or others? The egoist says: "I choose the first variant of behavior". And the altruist says: "I choose the second". But the wise man Hillel taught: "If I am not for myself, then who is for me? But if I am only for myself, then what for I am?"

5. Once the gentile asked the Jew: "Why even if you finish successfully your business, don't you enjoy yourself very much and even if you lost the game, don't you grieve too much?" And he got from the Jew such an answer: "No one success can be full - there are some elements of the possible loss in it, because of that we do not enjoy too much! And any loss cannot be full - it is always - has the elements of the possible winning in it, because of that we do not grieve too much".

6. "Why have the Jews studied so many commentaries in their holy books for centuries though these commentaries content many contradictions?" asked the gentile. The Rabbi answered that this commentaries were written by wise men so only keeping all commentaries even contradictions, we get the truth. We do not throw out the splinters of the broken diamond only because on one of them is written "Yes" and on others "No". All splinters are parts of one beautiful diamond.

7. All thinking people are parted on the people of faith and the people of mind. "And who are you, the Jews?" - once the gentile asked. And the Jew answered: "We are people of law. We do not crave for opening the world laws as the people of mind do and we do not crave to understand the wonder of the world laws as the people of faith do. Ideal world laws exist in the form of Torah and our problem is only to set up the conformity between the real world and Torah's laws and to expand the field of this accordance".

A huge number of Jewish short stories were collected and discussed in books [1], [2], [4], [5]. Notably, one of the first scholars, who started to philosophically analyze the Jewish short stories, was Sigmund Freud [3].

\section{Conclusion}

On the basis of hypothesis about many-valued logical interpretation of some Jewish short stories gives us possibility to understand the character of thinking of the Jews and their self-perceptions.

\section{References}

1. J. Allen. 500 Great Jewish Jokes. Signet, 1990.

2. A. Berger. The Genius of the Jewish Joke. Jason Aronson, 1997.

3. S. Freud. Der Witz und seine Beziehung zum Unbewußten. 1905. 
4. E. Oring. The Jokes of Sigmund Freud. University of Pennsylvania Press, 1984.

5. J. Telushkin. Jewish Humour: What the Best Jewish Jokes Say About the Jews. Harper Paperbacks, 1998. 